\title{
Emerging Importance of Self Regulation for Students During the Covid-19 Pandemic
}

\author{
Bony Irawan ${ }^{1}$, Andika Nur Hadianto $^{2}$, Nevrita $^{3}$, Erda Muhartati $^{4}$ \\ \{bony@umrah.ac.id ${ }^{1}$, andikanurhardianto@gmail.com², nevrita@umrah.ac.id ${ }^{3}$, \\ erdamuhartati@umrah.ac.id ${ }^{4}$ \}
}

Universitas Maritim Raja Ali Haji, Tanjungpinang, Kepulauan Riau Province, Indonesia ${ }^{1,2,3,4}$

\begin{abstract}
Distant learning imposed during school lockdown amidst the Covid-19 pandemic emphasized students' self-regulation. This study examined the correlation between self-regulation and learning achievement on high school and junior high school students during the full-time distant learning period of Covid lockdown. Students' selfregulation was assessed using a questionnaire, and the learning test result was obtained using validated instruments. Inferential statistics analyzed data to determine the correlation between students' self-regulation and learning achievement. Data analysis shows a positive correlation between good self-regulation and study results among both sample groups. Both junior high school and senior high school students with good self-regulation tend to score better on the test. This finding indicates that students with better self-regulation will likely thrive better in a highly independent learning environment of the Covid-19 pandemic.
\end{abstract}

Keywords: self-regulation, learning achievement, learning in the pandemic.

\section{Introduction}

Learning natural science is a distinct activity and exercise for students' learning effort [1]. Knowledge building of the learning process in the cognitive, affective, and psychomotor domains requires students to regulate their abilities actively and independently for a successful learning process [2]. Regulation of one's abilities is commonly referred to as self-regulation or, better known as self-regulation. Self-regulation is the ability of students to make their learning strategy plans and targets to be achieved in learning. It emphasizes the importance of personal responsibility and control over the knowledge and skills acquired [3]. Therefore, selfmanagement or self-regulation is the ability of students to regulate themselves in the learning activity by including metacognition, motivation, and active behaviour. Self-management is not a mental ability or academic ability but how individuals process and change their thoughts and habits [4].

In the learning process, self-management practised by students will beget knowledge and improve their cognitive skills by using metacognitive strategies in completing the tasks assigned to each student [5]. Students' success in managing themselves is very influential on the learning outcomes of students themselves in carrying out learning. Factors that greatly affect student learning outcomes are internal factors, namely self-regulation and external factors, which 
consist of; family environment, friends, and the surrounding environment, which also influence student learning. Each individual who learns will receive influences from various environments.

In the pandemic situation, learning has become more autonomous, and self regulation is predicted to have a greater influence on learning achievement [6]. Learning outcomes are used to determine how students understand and build their knowledge. Learning outcomes become a measurement of the assessment of learning activities or learning processes. It is one of the referenced parameters available to check students' learning achievement [7].

Biology is a subject that requires high autonomy and self regulation as with other STEM subjects. Distant learning in the Covid-19 pandemic increases challenges in biology learning everywhere. Students struggle with online learning in the archipelagic region like Riau Islands, mainly because of network and computer device availability. This problem has led to lower learning achievement in regions with the same challenges during the pandemic [8]. In addition to the low student scores, several problems occur, when the new teaching and learning process took place because of the coronavirus designated as a pandemic in Indonesia. Schools must ensure that teaching and learning activities continue even though students are at home. Teachers optimize the use of existing media such as online media. Because of this, students experience a decrease in learning outcomes. Students find it more difficult to understand learning material, as evidenced by the results of the assignments and exams given having low scores.

Autonomous and independent learning is predicted to become the new norm [9]. This trend will likely continue well beyond the restriction of the covid-19 pandemic. Leaders and education experts have started to migrate entirely into a more autonomous education policy. In preparation for this trend, students are expected to regulate their learning processes better. This study is conducted to examine how self-regulation correlates with learning achievement.

\section{Methods}

This research was conducted at SMA and SMP in Tanjungpinang. The sampling technique in this study used a probability sampling technique with random cluster sampling. Sampling using the Isaac and Michael methods by taking an error rate of 5\%, the number of samples taken is 150 . This study is correlational research that examines the correlation between students' selfregulation and learning achievement. Student's Self regulation were assessed using a validated questionnaire instrument. Biology test was administered to determine student's learning outcomes. Data were analyzed using regression statistics to determine the degree of correlation.

\section{Results and Discussion}

The distribution of the instruments carried out was obtained from self-regulation data and data on student biology learning outcomes. The calculations using regression statistics variable $\mathrm{X}$ and variable $\mathrm{Y}$ have a relationship (Adjusted R Square) of 0.7809 or $78.09 \%$. In addition, the $\mathrm{X}$ and $\mathrm{Y}$ variables have a high linear level (Multiple $\mathrm{R}$ ) of 0.8845 .

Table 1 shows the calculation of the correlation test using the Pearson Product Moment test. The calculated $r$-value is 0.88 , while the $r$ table value with a significance level of 0.05 , df $=139-2$ is 0.1401 . so the value of $r$ count $>r$ table. This study indicates a positive relationship between self-regulation and the biology learning outcomes of SMA and SMP students during the covid-19 pandemic. The results of this study are in accordance with Herawaty's study which found similar correlation between self-regulation and learning achievement [10] 
Table 1. Data regression on correlation of self regulation and learning outcome

Regression Statistics

\begin{tabular}{lr}
\hline Multiple R & 0,884594 \\
\hline $\boldsymbol{R}$ Square & 0,782506 \\
\hline Adjusted R Square & 0,780918 \\
\hline Standard Error & 9,856583 \\
\hline Observations & 139 \\
\hline
\end{tabular}

Earlier study from Azevedo et al. also states that self-regulation is an important factor in supporting students to obtain optimal achievement [11]. This finding explains that there is a relationship between self-regulation and student learning outcomes while relationship between self-regulation and learning outcomes has a significant relationship to improve student learning outcomes. One aspect of self-regulation is self evaluation. the evaluation referred to as positive self-evaluation makes students feel confident to learn and motivates them to continue to work diligently because they believe they can make further progress [12].

The embodiment of evaluation is related to learning outcomes. Learning outcomes are changes in students' abilities after experiencing the learning process [13]. This dictates that one of the personal factors that affect a person's achievement is the ability to self-regulate. Even in the case of students with good level of intelligence, personality, home environment, and a supportive school environment, without being supported by self-regulation abilities, the student will still not achieve optimal performance [14].

In addition, the positive effect caused has been proven empirically by several research results. Self-regulation will support the learning process carried out by students to achieve maximum learning outcomes. Students with good self-regulation will have good learning outcomes because they can organize their learning activities [15]. Self regulation also affected emotional aspect. Students who have good self-regulation usually able to better manage their emotional regulation [16].

This finding encourages teachers to promote student's self regulation. The emotional regulation possessed will allow students to monitor and evaluate their learning activities [17]. Some students even set consequences when they achieve or are not in the learning process when they do not carry out theirctivities as planned [18]. When teacher invloved students in learning planning, students might feel better satisfaction when they are able to meet the challenges of their schoolwork.

The existence of self-determined contingencies as a form of student self-regulation can further encourage students to prepare for learning, participate in the teaching and learning process, and follow up on the teaching and learning process to achieve optimal learning outcomes [19]. The better or higher the student's self-regulation, the better or higher the student's biology learning outcomes. Students who have a good motivation, metacognition, and behaviour have better learning outcomes. Meanwhile, students who have low levels of motivation, metacognition, and behaviour have lower learning achievements. 


\section{Conclusion}

This study concludes that there is a positive correlation between students' self regulation and learning outcome. Students with better self regulation tend to score better in learning achievement test.

\section{References}

[1] León J, Núñez JL, Liew J. Self-determination and STEM education: Effects of autonomy, motivation, and self-regulated learning on high school math achievement. Learning and Individual Differences. 2014 Sep 22;43:156-63.

[2] Butler DL, Simon PHW, Unnversity F. Feedback and Self-Regulated Learning: A Theoretical Synthesis. Vol. 65. Winne; 1995.

[3] Dunlosky J, Ariel R. Self-Regulated Learning and the Allocation of Study Time. Vol. 54, Psychology of Learning and Motivation - Advances in Research and Theory. 2011. 103-140.

[4] Newman RS. How self-regulated learners cope with academic difficulty: The role of adaptive help seeking. Theory into Practice. 2002;41(2):132-8.

[5] Benjamin AS, Bird RD. Metacognitive control of the spacing of study repetitions. Journal of Memory and Language. 2006 Jul;55(1):126-37.

[6] Holzer J, Lüftenegger M, Käser U, Korlat S, Pelikan E, Schultze-Krumbholz A, et al. Students' basic needs and well-being during the COVID-19 pandemic: A two-country study of basic psychological need satisfaction, intrinsic learning motivation, positive emotion and the moderating role of self-regulated learning. International Journal of Psychology. 2021 Dec 1;

[7] van de Schoot R, Lugtig P, Hox J. A checklist for testing measurement invariance. European Journal of Developmental Psychology. 2012 Jul;9(4):486-92.

[8] Yang M, Mak P, Yuan R. Feedback Experience of Online Learning During the COVID-19 Pandemic: Voices from Pre-service English Language Teachers. The AsiaPacific Education Researcher [Internet]. 2021 Dec 26;30(6):611-20. Available from: https://link.springer.com/10.1007/s40299-021-00618-1

[9] Paechter M, Maier B. Online or face-to-face? Students' experiences and preferences in e-learning. Internet and Higher Education. 2010 Dec;13(4):292-7.

[10] Herawaty H, Dalimunthe B, Sutisna A, Zakiah L, Handayani S. Transformati YH Science Education : Empowering Self Regulated Learners G uring Pandemic COVID19. 2020;(Smic):1-5.

[11] Azevedo R, Moos DC, Greene JA, Winters FI, Cromley JG. Why is externallyfacilitated regulated learning more effective than self-regulated learning with hypermedia? Educational Technology Research and Development. 2008 Feb;56(1):45-72.

[12] Ariel R, Dunlosky J, Bailey H. Agenda-Based Regulation of Study-Time Allocation: When Agendas Override Item-Based Monitoring. Journal of Experimental Psychology: General. 2009 Aug;138(3):432-47.

[13] van den Broeck A, Ferris DL, Chang CH, Rosen CC. A Review of Self-Determination Theory's Basic Psychological Needs at Work. Journal of Management. 2016 Jul 1;42(5):1195-229. 
[14] Ryan RM, Deci EL. Self-Determination Theory and the Facilitation of Intrinsic Motivation, Social Development, and Well-Being Self-Determination Theory. Ryan; 1985.

[15] Reeve J, Jang H. What teachers say and do to support students' autonomy during a learning activity. Vol. 98, Journal of Educational Psychology. 2006. p. 209-18.

[16] Britton BK, Tesser A. Effects of Time-Management Practices on College Grades. Vol. 83, Journal of Educational Psychology. 1991.

[17] Bong M. Between-and Within-Domain Relations of Academic Motivation Among Middle and High School Students: Self-Efficacy, Task-Value, and Achievement Goals. Journal of Educational Psychology. 2001;93(1):23-34.

[18] Niemiec CP, Ryan RM. Autonomy, competence, and relatedness in the classroom:Applying self-determination theory to educational practice. Theory and Research in Education. 2009;7(2):133-44.

[19] de Bruin ABH, Rikers RMJP, Schmidt HG. Monitoring accuracy and self-regulation when learning to play a chess endgame. Applied Cognitive Psychology. 2005 Mar;19(2):167-81. 